\title{
Kebijakan Penataan dan Pengelolaan Parkir Sebagai Upaya Peningkatan Pendapatan Asli Daerah
}

\author{
Imam Asmarudin ${ }^{1}$, Imawan Sugiharto ${ }^{2}$, Ratna Riyanti ${ }^{3}$, Hamidah Abdurrachman ${ }^{4}$ \\ Universitas Pancasakti Tegal \\ Masuk: 12 November 2020; Diterima: 30 November 2020; Terbit: 30 November 2020.
}

DOI: $10.24905 /$ diktum.v8i2.100

\begin{abstract}
The purpose of this research is to explore how the potential of local native income from the sector of structuring the management of expertise in Tegal Regency. Taxes and levies are one of the sources of local income that can be returned to the community as a form of welfare, the form of return from local government are to provide good public services, orderly, safe and comfortable, one of which is in parking, management and arrangement of parking is a business that has income value. This research uses an empirical juridical approach where primary data is the main data, data obtained through observation and interview, then data processed descriptively analytically. Retribution is one of the sources of revenue Tegal regency should be selectively optimized. The arrangement of parking, management is expected to increase the income of the area as the original income of the region and vice versa for the community to feel its benefits, comfort, order, and security in parking. Based on data in 2020 Tegal district government has a total parking location point of 269 with parkers as many as 412 people, if the levy is carried out correctly and by the nominal deposited estimated Local Native Income from the parking management sector reaches Rp. 697,488,000,000. Seeing this potential requires policy breakthroughs for local governments in managing to park, one of which is by making Local Regulations on Parking Arrangement and Management
\end{abstract}

Keywords: Structuring and Management, Parking, Local Native Income

\footnotetext{
${ }^{1}$ Coresponding author:

imam_asmarudin@upstegal.ac.id
} 


\begin{abstract}
Abstrak
Tujuan penelitian ini adalan meeliti mengenai bagaimana potensi pendapatan asli daerah dari sektor penataan pengelolaan perpakiran di Kabupaten Tegal. Pajak dan retribusi merupakan salah satu sumber pendapatan daerah yang dapat dikembalikan lagi kepada masyarakat sebagai bentuk kesejahteraan, bentuk pengembalian dari Pemerintah Daerah adalah dengan memberikan pelayanan publik yang baik, tertib, aman dan nyaman, salah satunya adalah dalam perparkiran, pengelolaan dan penataan parkir merupakan usaha yang memiliki nilai pendapatan. Penelitian ini menggunakan pendekatan yuridis empiris dimana data primer merupakan data utama, data diperoleh melalui observasi dan wawancara, kemudian data diolah secara deskriptif analitis. Retribusi merupakan salah satu sumber pendapatan pemerintah Kabupaten Tegal harus secara selektif dapat dioptimalkan. Dengan adanya penataan pengelolaan perparkiran diharapkan akan menambah pemasukan daerah sebagai pendapatan asli daerah dan sebaliknya bagi masyarakat merasakan kebermanfaatannya, kenyamanan, ketertiban dan keamanan dalam parkir. Berdasarkan data pada tahun 2020 Pemerintah Daerah Kabupaten Tegal memiliki total titik lokasi parkir sebanyak 269 dengan juru parker sebanyak 412 orang, apabila pungutan tersebut dilakukan secara benar dan sesuai dengan nominal yang disetorkan diperkirakan Pendapatan Asli Daerah dari sektor penataan pengelolaan perparkiran mencapai Rp. 697.488.000.000. Melihat potensi ini diperlukan terobosan kebijakan bagi pemerintah daerah dalam melakukan pengelolaan parkir, salah satunya adalah dengan membuat Peraturan Daerah tentang Penataan dan Pengelolaan Parkir
\end{abstract}

Kata kunci: Penataan dan Pengelolaan, Parkir, Pendapatan Asli Daerah

\title{
A. Pendahuluan
}

Undang-Undang Dasar Negara Republik Indonesia Tahun 1945 Pasal 18 ayat 2 menyatakan bahwa Pemerintah Daerah Propinsi, Daerah Kabupaten, dan kota mengatur dan mengurus sendiri urusan pemerintahan menurut asas otonomi dan tugas pembantuan. (Syamsu, 2012) Sesuai ketentuan yang tertuang dalam konstitusi tersebut maka Pemerintah sudah selayaknya melaksanakan asas-asas dalam penyelenggaraan Otonomi Daerah, yakni Asas Desentralisasi, Asas Dekosentrasi dan Tugas Pembantuan yang dapat memudahkan mengatur (to regulate) dan mengkoordinir kegiatan pemerintah (control to the government activity) dan pembangunan yang ada di daerah dalam wilayah Negara Kesatuan Republik Indonesia. Sebagai pelaksanaan dari ketentuan tersebut saat ini telah berlaku undang-undang organik pelaksana dari Konstitusi, yakni Undang-Undang nomor 23 tahun 2014 Pemerintahan Daerah beserta perubahannya terakhir dengan Undang-undang nomor 9 tahun 2015 tentang Perubahan kedua Undang-Undang nomor 23 tahun 2014 Pemerintahan Daerah. (Hadi, 2003) 
Kewenangan Pemerintah Daerah yang diberikan oleh undang-undang memberikan peluang bagi Pemerintah Daerah dalam mengelola dan melakukan manajemen pengelolaan keuangan daerah secara mandiri, Pemerintah Daerah dapat melakukan penggalian sumber-sumber Pendapatan Asli Daerah untuk peningkatan pembangunan daerah maupun kesejahteraan masyarakatnya. Mengingat Pendapatan Asli Daerah merupakan sumber pendapatan daerah yang berasal dari kegiatan ekonomi daerah itu sendiri, artinya pendapatan asli daerah adalah pendapatan yang diperoleh dari aktivitas pengelolaan potensi asli daerah sesuai dengan peraturan perundangundangan yang berlaku. (Iskandar, 1998)

Pendapatan Asli Daerah (PAD) merupakan salah satu pilar kemandirian suatu daerah. Menurut Undang-Undang Nomor 33 Tahun 2004 tentang perimbangan keuangan antara pemerintah pusat dan daerah, sumber PAD terdiri dari pajak daerah, retribusi daerah, hasil pengelolaan kekayaan daerah, dan lain-lain pendapatan daerah yang sah. Pengelolaan pendapatan asli daerah yang efektif dan efisien perlu dilaksanakan dengan mempertimbangkan kondisi ekonomi daerah maupun perekonomian nasional. Kontribusi yang dicapai dari pendapatan asli daerah dapat terlihat dari seberapa besar pendapatan tersebut disalurkan untuk membangun daerah agar lebih berkembang dan mampu meningkatkan kesejahteraan masyarakat. (Nurmandi, 2006)

Kabupaten Tegal sebagai wilyah yang memiliki 18 Kecamatan dan 6 Kelurahan memiliki potensi sumber pendapatan asli daerah yang maksimal, Salah satu potensi Pendapatan Asli Daerah Kabupaten Tegal adalah dari sektor parkir Seiring dengan meningkatnya penggunaan kendaraan serta perpindahan masyarakat dari satu tempat ke tempat lainnya paralel dengan kebutuhan masyarakat akan lahan atau ruang parkir, menjadikan 
parkir sebagai elemen terpenting dalam transportasi parkir serta beralih menjadi potensi sumber dana yang potensial bagi pemerintah daerah.

Penataan perparkiran menjadi point penting dalam menjaga kenyamanan, ketertiban dan keamanan dari para pengguna parkir, tingginya mobilitas orang khususnya masyarakat perkotaan tentunya harus diimbangi oleh sarana dan prasarana demi terwujudnya kelancaran transportasi. Penataan pengelolaan parkir di Kabupaten Tegal, harus terus dilakukan pembenahan. Mulai dari rencana pengelolaan parkir dari sistem swakelola menjadi sistem lelang terbuka.

Pada tahun 2016 dan tahun 2018 Penataan perparkiran di Kabupaten Tegal pernah dilakukan dengan sistem lelang terbuka dengan melibatkan pihak ketiga dalam pengelolaan perparkirannya, namun kenyataannya dalam pelaksanannya terdapat kendala, seperti tidak validnya data survei dikarenakan adanya dobel nama titik parkir, dan data dinilai semrawut, adanya benturan fisik di lapangan, kendala lainnya berupa proyek perbaikan jalan di sejumlah tempat, sehingga lahan parkir hilang. Dengan adanya kendala tersebut pihak ketiga yang yang seharusnya memberikan pemasukan sebagai Pendapat Asli Daerah dengan target yang sudah disepakati namun pihak ketiga tidak mampu untuk memenuhi target tersebut yang berdampak pada Pendapatan Asli Daerah dari sektor perparkiran menurun dibawah Rp. 1.000.000.000,- (satu milyar rupiah) per tahun, dan hal tersebut menjadi persoalan yang harus dicarikan solusi agar target pendapatan Asli Daerah dari Sektor perparkiran dapat memenuhi diatas Rp. Rp. 1.000.000.000.,- (satu milyar rupiah).

Kondisi saat ini tahun 2020, di Pemerintah Kabupaten Tegal, berdasarkan data dari Dinas Perhubungan (DISHUB) Kabupaten Tegal memiliki data pengelolaan Retribusi Parkir tahun 2020 yang tersebar di 16 (enam belas) Kecamatan, dari 16 (enam belas) kecamatan tersebut terdapat 269 titik lokasi 
Parkir dan terdapat juru parkir (Jukir) sebanyak 412 Juru Parkir, dengan target PAD dari sektor parkir diperkirakan Rp. 1.2 Milyar.

Selama ini dalam pelaksanaan penataan dan pengelolaan parkir di Kabupaten Tegal yang dilakukan oleh Dinas Perhubungan (DISHUB) belum memiliki payung hukum yang maksimal, belum ada Peraturan Daerah yang mengatur khusus menyangkut penataan dan pengelolaan parkir, apabila dari pemerintah daerah memiliki kebijakan secera tegas dalam bentuk Peraturan Daerah, maka potensi pendapatan asli daerah dari sektor parkir dapat meningkat, berdasarkan hal itu Penulis mencoba membuat kajian dalam bentuk sebuah artikel, yang menguraikan menyangkut penataan dan pengelolan parkir sebagai sumber potensi pendapatan asli daerah Kabupaten Tegal untuk mencari diteliti mengenai bagaimana potensi Pendapatan Asli Daerah dari sektor penataan pengelolaan perpakiran di Kabupaten Tegal.

\section{Metodologi Penelitian}

Metodologi merupakan suatu unsur yang mutlak harus ada di dalam penelitian dan pengembangan ilmu pengetahuan. Metode yang digunakan adalah metode yuridis empiris yang dilengkapi dengan diskusi (focus group discussion) dan pengamatan di lapangan. Metode yuridis empirs adalah metodologi penelitian hukum yang mengkaji implementasi suatu peraturan perundang-undangan di masyarakat untuk melihat efektifitas hukumnya. (Soekanto, 2006) Pendekatan yuridis empiris menggunakan data yang diperoleh dari Penelitian Kepustakaan (Library Research) yakni Penulis mengumpulkan bahan-bahan seperti peraturan perundang-undangan dan literatur karya ilmiah seperti jurnal untuk dikaji dan ditelaah, dan juga buku-buku yang berkaitan dengan pajak, retribusi dan pendapatan asli daerah. selain itu dilakukan Penelitian Lapangan (field research) yakni Penelitian dilakukan di lapangan untuk menguji implementasi peraturan dan teori hukum. Data dianalisis secara kualitatif dengan menjelaskan persoalan retribusi dan perparkiran secara 
khusus kepada persoalan yang umum, manfaatnya untuk mempermudah penjelasan mengenai kajian parkir, retribusi, dan pendapatan asli daerah. (Pratama, 2020)

\section{Pembahasan}

\section{Kewenangan Pengelolaan Parkir Daerah}

Kewenangan berasal dari kata dasar wewenang yang berarti sebagai hal berwenang, hak dan kekuasaan yang dipunyai untuk melakukan sesuatu. Kewenanangan adalah kekuasaan formal, kekuasaan yang diberikan oleh Undang-Undang atau dari kekuasaan eksekutif administrasi. Menurut Philipus M. Hadjon, "wewenang (bevoegdheid) dideskripsikan sebagai kekuasaan hukum (rechtsmacht). Jadi dalam konsep hukum publik, wewenang berkaitan dengan kekuasaan. (Hadjon, 1997)

Menurut Ateng Syafrudin ada perbedaan antara pengertian kewenangan dengan wewenang, kewenangan (autority gezag) adalah apa yang disebut kekuasaan formal, kekuasaan yang berasal dari kekuasaan yang diberikan oleh Undang-Undang, sedangkan wewenang (competence bevoegheid) hanya mengenai suatu onderdeel (bagian) tertentu saja dari kewenangan. Didalam kewenangan terdapat wewenang-wewenang (rechtsbe voegdheden). Wewenang merupakan lingkup tindakan hukum publik, lingkup wewenang pemerintahan, tidak hanya meliputi wewenang membuat keputusan pemerintah (bestuur), tetapi meliputi wewenang dalam rangka pelaksanaan tugas, dan memberikan wewenang serta distribusi wewenang utamanya ditetapkan dalam peraturan perundangundangan. (Syafrudin, 2000)

Pengertian wewenang secara yuridis adalah kemampuan yang diberikan oleh peraturan perundang-undangan untuk menimbulkan akibat-akibat hukum. Wewenang menurut H.D. Stoud adalah "bevoegheid wet kan worden omscrevenals het geheel van bestuurechttelijke bevoegheden door 
publiekrechtelijke rechtssubjecten in het bestuurechttelijke rechtsverkeer" bahwa wewenang dapat dijelaskan sebagai keseluruhan aturan-aturan yang berkenaan dengan perolehan dan penggunaan wewenang pemerintah oleh subjek hukum publik dalam hukum publik. (William, 2003)

Salah satau kewenangan yang ada adalah dalam sistem pengelolaan pemerintahan, Penyerahan kewenangan pemerintah dari pusat ke daerah berasaskan otonomi daerah selama ini telah berjalan dan merupakan bagian dari pelaksanaan pemberian kewenangan secara legal, karena diatur dalam peraturan perundang-undangan. Dalam perjalanannya tersebut, peraturan perundang-undangan telah berganti berulang kali. Berawal dari Undang - Undang nomor 22 tahun 1999 tentang Pemerintahan Daerah hingga saat ini Undang - Undang nomor 9 tahun 2015 tentang Perubahan Kedua atas Undang - Undang nomor 23 tahun 2014 tentang Pemerintahan Daerah adalah peraturan yang menjadi payung hukum otonomi daerah bagi pemerintah daerah dalam menyusun, mengatur, dan mengurus daerahnya di seluruh aspek secara mandiri tanpa adanya intervensi dari Pemerintah Pusat. Otonomi daerah telah banyak membawa implikasi positif terhadap daerah - daerah untuk lebih mandiri dan mengetahui segala hal yang dibutuhkan oleh daerahnya dan semakin mudah untuk melakukan pemeratan pembangunan di seluruh wilayah Indonesia. (Hadjon, 1997)

Upaya menjalankan otonomi daerah, Pemerintah Daerah mempunyai hak dan kewajiban mengatur dan mengurus sendiri urusan pemerintahannya untuk meningkatkan efisiensi dan efektifitas, penyelenggaraan pemerintahan dan pelayanan kepada masyarakat. Salah satunya dengan cara melakukan pungutan terhadap masyarakatnya. Undang - Undang Nomor 28 tahun 2009 tentang Pajak Daerah dan Retribusi Daerah bertujuan agar Pemerintah Daerah mempunyai 
kewenangan untuk melakukan pemungutan Pajak Daerah dan Retribusi Daerah (PDRD) kepada masyarakat, yang mana hasil dari pemungutan PDRD tersebut akan digunakan untuk membiayai pembangunan dalam rangka memberikan pelayanan kepada masyarakat serta meningkatkan kesejahteraan masyarakat. (Fachruddin, 2004)

\section{Konsep Kebijakan Publik Pengelolaan Parkir}

Kebijakan pemerintah daerah perlu dilakukan dalam rangka sebagai pemecah atau solusi manakala terjadi persoalan, salah satu kebijakan yang perlu dilakukan oleh Pemerintah Daerah adalah dalam pengggalian sumber-sumber Pendapatan Asli Daerah, salah satu sumber pendapatan adalah dari sektor parkir yang sangat berpotensi memberikan kontribusinya, sehingga Perlu ada penataan pengelolaan perparkiran dengan memperhatikan Strategi pengelolaan Parkir. (Budi, 2002. )

Kebijakan Publik merupakan suatu aturan-aturan yang dibuat oleh pemerintah dan merupakan bagian dari keputusan politik untuk mengatasi berbagai persoalan dan isu-isu yang ada dan berkembang di masyarakat. Kebijakan publik juga merupakan keputusan yang dibuat oleh pemerintah untuk melakukan pilihan tindakan tertentu untuk tidak melakukan sesuatu maupun untuk melakukan tidakan tertentu. (Suwarno, 2012)

Menurut Wiliiam N. Dunn, Kebijakan Publik (Public Policy) adalah Pola ketergantungan yang kompleks dari pilihan-pilihan kolektif yang saling tergantung, termasuk keputusan-keputusan untuk tidak bertindak, yang dibuat oleh badan atau kantor pemerintah. Kebijakan publik merupakan arah tindakan yang mempunyai maksud yang ditetapkan oleh seorang aktor atau sejumlah aktor dalam mengatasi suatu masalah atau suatu persoalan. (William, 2003) 
Kebijakan publik dalam prakteknya baiknya harus mengandung unsur-unsur sebagai berikut: (Nawawi, 2009)

a. Kebijakan selalu mempunyai tujuan atau berorientasi pada tujuan tertentu.

b. Kebijakan berisi tindakan atau pola tindakan pejabat-pejabat pemerintah.

c. Kebijakan adalah apa yang benar-benar dilakukan oleh pemerintah, dan bukan apa yang bermaksud akan dilakukan.

d. Kebijakan publik bersifat positif (merupakan tindakan pemerintah mengenai sesuatu masalah tertentu) dan bersifat negatif (keputusan pejabat pemerintah untuk tidak melakukan sesuatu).

e. Kebijakan publik (positif), selalu berdasarkan pada peraturan perundangan tertentu yang bersifat memaksa (otoritatif).

f. Bentuk-bentuk Kebijakan Publik

Terbitnya kebijakan publik dilandasi kebutuhan untuk penyelesaian masalah yang terjadi di masyarakat. Kebijakan publik ditetapkan oleh para pihak (stakeholders), terutama pemerintah yang diorientasikan pada pemenuhan kebutuhan dan kepentingan masyarakat. Makna dari pelaksanaan kebijakan publik merupakan suatu hubungan yang memungkinkan pencapaian tujuan-tujuan atau sasaran sebagai hasil akhir dari kegiatan yang dilakukan pemerintah. Kekurangan atau kesalahan kebijakan publik akan dapat diketahui setelah kebijakan publik tersebut dilaksanakan, keberhasilan pelaksanaan kebijakan publik dapat dilihat dari dampak yang ditimbulkan sebagai hasil evaluasi atas pelaksanaan suatu kebijakan. (Rohman A. T., 2016)

Sifat kebijakan publik perlu dituangkan menjadi sebuah peraturanperaturan perundangan agar memiliki daya atau sifat memaksa. artinya, dapat diasumsikan bahwa kebijakan publik merupakan kebijakan yang 
dibuat pemerintah baik pusat ataupun Pemerintah Daerah yang berorientasi pada kesejahteraan masyarakat, yang dapat diwujudkan berupa peraturan-peraturan, perundang-undangan dan sebagainya. Dalam hal ini Pemerintah Kabupaten Tegal dengan Peraturan Daerah. Kebijakan publik mempunyai sifat mengikat dan harus dipatuhi oleh seluruh anggota masyarakat tanpa terkecuali. Sebelum kebijakan publik tersebut diterbitkan dan dilaksanakan, kebijakan tersebut harus ditetapkan dan disahkan oleh badan/ lembaga yang berwenang, apabila lembaga tersebut didaerah maka Dewan Perwakilan Rakyat Daerah (DPR yang memiliki fungsi tersebut, yakni fungsi legislasi. (Rohman A. T., 2016)

Dengan adanya konsep Kebijakan Publik sebagaimana diuaraikan diatas, maka Pemerintah Daerah memiliki peluang dalam meningkatkan pendapatan asli daeraj melalui sektor parkir dengan membuat kebijakan berupa pembentukan Peraturan Daerah terkait penataan dan pengelolaan parkir di Pemerintah Daerah Kabupaten Tegal.

3. Potensi Pendapatan Asli Daerah Dari Sektor Penataan Pengelolaan Perpakiran Di Kabupaten Tegal

Kabupaten Tegal sendiri merupakan salah satu wilayah daerah yang memiliki potensi lahan parkir di tepi jalan umum yang cukup banyak dan dengan jumlah pengendara motor yang terus bertambah dari tahun ke tahun. Kabupaten Tegal saat ini memiliki titik lokasi parkir sekitar 215 lokasi yang tersebar di 16 Kecamatan, serta juru parkir sejumlah 348 orang. Retribusi parkir di tepi jalan umum sangat berpotensi dalam menyumbangkan pendapatan retribusi bagi keberlangsungan pembangunan di Kabupaten Tegal. Sistem penataan pengelolaan perparkiran perlu dilakukan untuk mencari solusi dalam peningkatan Pendapatan Asli Daerah (PAD) Kabupaten Tegal. Strategi dan terobosan harus dilakukan oleh Pemerintah Daerah Kabupaten Tegal dalam 
mengatasi minimnya pemasukan pendapatan daerah dari sektor perparkiran.

Pengaturan penataan pengelolaan tempat parkir pada dasarnya memiliki beberapa tujuan yaitu: (Rye, 2011)

a. Menghindari penumpukan kendaraan dibahu jalan yang tidak teratur dan mengatur kelancaran lalu lintas dijalan;

b. Mengatur kendaraan yang sedang parkir dengan mempertimbangkan dampak - dampak yang ditimbulkan;

c. Menjamin keteraturan lingkungan, ketertiban

lingkungan, dan kenyamanan lingkungan ketika suatu tempat dijadikan sebagai lahan parkir;

d. Mengantisipasi dan meminimalisasi tindak pidana kejahatan pada kendaraan yang sedang parkir; dan

e. memberikan jaminan perlindungan kepada masyarakat yang memarkir kendaraannya.

Pengaturan terhadap Pengelolaan Tempat Parkir seperti tempat parkir yang berada di mall - mall, tempat parkir yang disediakan di pertokoan, tempat parkir di tepi jalan raya, sampai dengan tempat - tempat parkir lainnya yang ada di perkantoran baik yang dikelola oleh pemerintah daerah maupun swasta.

Pengelolaan parkir di wilayah Kabupaten Tegal dilakukan swakelola sendiri oleh Dinas terkait yakni Dinas Perhubungan (DISHUB) Kabupaten Tegal, meskipun sebelumnya pernah dilakukan pengelolaannya dengan melibatkan pihak ketiga, yakni, pada bulan Januari tahun 2016 sampai dengan bulan Desember 2016 pegelolaan parkir di Kabupaten Tegal pernah dilakukan oleh Organisasi Masyarakat (ormas) Pemuda Pancasila (PP), pada bulan Februari 2018 sampai dengan Desember 2018 pengelolaan parkir dilakukan oleh PT. Kaboa Jaya Sentosa. 
Namun dalam pelaksanannya terdapat berbagai kendala yang berakibat target Pendapatan Asli Daerah Kabupaten Tegal tidak terpenuhi, sehingga perlu ada evaluasi yang mendalam, dan sambil menunggu pengelolaan tetap harus berjalan dan di serahkan kepada Dinas Perhubungan (DISHUB) Kabupaten Tegal sebagai dinas terkait yang melakukan penataan pengelolaan perparkiran yang ada di Kabupaten Tegal.

Dari data yang diperoleh penulis menunjukan bahwa target pendapatan yang ditargetkan dalam perjanjian dengan PT. Kaboa Jaya Sentosa adalah sekitar Rp. 646.250.000,- (enam ratus empat puluh enam juta dua ratus lima puluh ribu rupiah) pertahun namun dalam pelaksanaannya PT. Kaboa Jaya Sentosa tidak mampu memenuhi target dan hanya mampu merealisasikan $50 \%$ dari penawaran nya saja, yakni sekitar Rp. 323.125.000 (tiga ratus dua puluh tiga juta seratus dua puluh lima ribu rupiah).

Berdasarkan data Dinas Perhubungan Darat pada tahun 2020, di Pemerintah Kabupaten Tegal, berdasarkan data dari Dinas Perhubungan (DISHUB) Kabupaten Tegal memiliki data pengelolaan Retribusi Parkir tahun 2020 yang tersebar di 16 (enam belas) Kecamatan yakni, Kecamatan Adiwerna, Balapulang, Bojong, Bumijawa, Dukuhturi, Jatinegara, Kedungbanteng, Kramat, Lebaksiu, Margasari, Pagerbarang, Pangkah, Slawi, Suradadi, Talang, Tarub

Dari 16 (enam belas) kecamatan tersebut terdapat 269 titik lokasi Parkir dan terdapat 412 Juru Parkir (Jukir) di Pemerintah Kabupaten Tegal. Dari hasil pemetaan jumlah titik lokasi parkir yang ada tersebut diharapkan perolehan Pendapatan Asli Daerah Kanbupaten Tegal dapat mencapai diatas Rp. 1.000.000.0000,- (satu milyar rupiah), bahkan dari hasil pemetaan Dinas Perhubungan (DISHUB) Kabupaten Tegal apabila 
semua lancar diperkirakan dana yang masuk sebesar Rp. 1.200.000.000,(satu milyar dua ratus juta rupiah).

Proyeksi pendapatan parkir setiap titik lokasi parkir disetiap kecamatan, dari hasil data yang diperoleh penulis dari DISHUB Kabupaten Tegal diperoleh data proyeksi dari DISHUB Kabupaten Tegal terhadap pendapatan dari sektor parkir setiap kecamatan di Kabupaten Tegal yang dapat menjadi pemasukan PAD:

Tabel.1

\begin{tabular}{|r|l|r|}
\hline No. & \multicolumn{1}{|c|}{ Kecamatan } & $\begin{array}{r}\text { Besaran yang disetorkan ke Pemda } \\
\text { (pertahun dalam Rp) }\end{array}$ \\
\hline 1. & Kramat & $64.512 .000,-$ \\
\hline 2. & Dukuhturi & $21.024 .000,-$ \\
\hline 3. & Adiwerna & $114.912 .000,-$ \\
\hline 4. & Talang & $4.560 .000,-$ \\
\hline 5. & Lebaksiu & $28.224 .000,-$ \\
\hline 6. & Pangkah & $48.384 .000,-$ \\
\hline 7. & Jatinegara & $9.504 .000,-$ \\
\hline 8. & Kedungbanteng & $8.064 .000,-$ \\
\hline 9. & Balapulang & $42.048 .000,-$ \\
\hline 10. & Margasari & $54.144 .000,-$ \\
\hline 11. & Slawi & $230.688 .000,-$ \\
\hline 12. & Bumijawa & $51.840 .000,-$ \\
\hline 13. & Bojong & $8.640 .000,-$ \\
\hline 14. & Suradadi & $5.472 .000,-$ \\
\hline 15. & Tarub & $4.032 .000,-$ \\
\hline 16. & Pagerbarang & $1.440 .000,-$ \\
\hline & TOTAL & 697.488 .000 .000 \\
\hline
\end{tabular}

Sumber: Dinas Perhubungan Kabupaten Tegal

Dari jumlah total titik lokasi parkir sebanyak 269 (dua ratus enam puluh sembilan) dengan juru parkirm(Jukir) sebanyak 412 (empat ratus dua belas) orang, apabila pungutan tersebut dilakukan secara benar dan sesuai dengan nominal yang disetorkan diperkirakan Pendapatan Asli Daerah (PAD) dari sektor penataan pengelolaan perparkiran mencapai Rp. 
697.488.000.000,- (enam ratus Sembilan puluh tujuh juta empat ratus delapan puluh delapan ribu rupiah).

Dengan potensi yang ada, pendapatan dari sektor dalam pengelolaan parkir masih dapat ditingkatkan lagi, bahkan dapat diupayakan dengan Target sampai dengan diatas Rp. 1 Milyar rupiah, oleh karenanya diperlukan terobosan kebijakan bagi pemerintah daerah dalam melakukan pengelolaan parkir, salah satunya adalah dengan membuat Peraturan Daerah. oleh karenanya dalam penentuan pengelola penarikan pungutan parkir harus ada kejelasan dan ketegasan bagi pemerintah daerah apabila menggunakan pihak ketiga dalam pelaksanaannya, perlu diberikan payung hukum yang tegas, termasuk dalam pelaksanaannya pihak ketiga tidak mampu untuk memenuhi target PAD yang diperjanjikan dalam kesepakatan maka perlu ditegaskan terkait dengan konsekuensi hukumnya, apakah perlu diberikan sanksi baik keperdataan atau pidana sesuai dengan ketentuan hukum yang berlaku.

Saat ini Peraturan Daerah di Pemerintah Kabupaten Tegal baru hanya ada Peraturan Daerah Kabupaten Tegal tentang Retribusi Daerah beserta perubahannya, oleh karena itu perlu ada aturan yang yang berbentuk Peraturan Daerah untuk mengatur mengenai penataan pengelolaan perparkiran, yang tujuan utamanya adalah selain untuk ketertiban, kenyamanan para pengguna parkir akan tetapi juga dengan semakin tertib, teratur, aman setiap masyarakat yang memarkirkan kendaraanya dalam keadaan aman dan baik, maka secara tidak langsung akan membuat peningkatan Pendapatan Daerah dari sektor parkir. Dengan adanya rencana Peraturan Daerah tentang penataan pengelolaan perparkiran diharapkan dapat terselenggaranya kondisi perparkiran yang tertib, aman dan nyaman serta mampu memberikan sumbangan terhadap PAD Kabupaten Tegal sesuai dengan target yang telah ditetapkan. 


\section{Simpulan}

Selama ini Pemerintah Kabupaten Tegal belum memiliki kebijakan dalam bentuk Peraturan Daerah yang menfokuskan pada penataan dan pengelolaan perparkiran, selama ini kebijakan terkait parkir masih sebatas Peraturan Daerah tentang Retribusi Daerah yang mengatur salah satunya adalah terkait Retribusi Parkir yang mengatur besaran pungutan Parkir, obyek parkir, dan tata cara pungutan, namun menyangkut penataan dan pengelolaan belum diatur secara spesifik dalam Peraturan Daerah tersendiri, mengingat dalam penataan pengelolaan selain menata agar perparkiran di Pemerintah Kabupaten Tegal lebih tertib, aman, nyaman, penataan dan pengelolaan parkir juga diharapkan tidak mengakibatkan gangguan bagi kelancaran aktifitas masyarakat lainnya terutama dalam berlalu lintas dijalan. Oleh karenanya diperlukan adanya kebijakan menyangkut hal tersebut dalam bentuk sebuah Peraturan Daerah agar Pemerintah Daerah memiliki payung hukumnya.

Melihat hasil data yang di telah dibahas dalam Bab sebelumnya, potensi dari sektor parkir memiliki potensi besar menunjang pemasukan bagi Pendapatan Asli Daerah Pemerintah Daerah Kabupaten Tegal, mengingat saat ini berdasarkan data dari DISHUB pada tahun 2020 Pemerintah Daerah Kabupaten Tegal memiliki total titik lokasi parkir sebanyak 269 (dua ratus enam puluh sembilan) dengan juru parkirm(Jukir) sebanyak 412 (empat ratus dua belas) orang, apabila pungutan tersebut dilakukan secara benar dan sesuai dengan nominal yang disetorkan diperkirakan Pendapatan Asli Daerah (PAD) dari sektor penataan pengelolaan perparkiran mencapai Rp. 697.488.000.000,(enam ratus Sembilan puluh tujuh juta empat ratus delapan puluh delapan ribu rupiah). Dengan potensi yang ada, pendapatan dari sektor dalam pengelolaan parkir masih dapat ditingkatkan lagi, bahkan dapat diupayakan dengan Target sampai dengan diatas Rp. 1 Milyar rupiah, oleh karenanya diperlukan terobosan kebijakan bagi pemerintah daerah dalam melakukan pengelolaan parkir, salah 
satunya adalah dengan membuat Peraturan Daerah tentang Penataan dan Pengelolaan Parkir.

\section{Daftar Pustaka}

Abubakar, I. (1996). Manajemen Transportasi Perkotaan. . Jakarta: Sekertariat Masyarakat Transportasi Indonesia.

Bruggink, J. (Refleksi Tentang Hukum: Pengertian-Pengertian Dasar dalam Teori Hukum). 1996. Bandung: PT. Citra Aditya Bakti.

Budi, W. ( 2002. ). Teori dan Proses Kebijakan Publik. Yogyakarta: Media Pressindo.

Fachruddin, I. (2004). Pengawasan Peradilan Administrasi terhadap Tindakan Pemerintah. Bandung: Alumni.

Friedman, L. M. (2009 ). Sistem Hukum Persfektif Ilmu Sosial, The Legal System; A Social Science Perspective. , Bandung: Nursamedia.

Hadi, N. A. (2003). Organisasi dan Manajemen Pemerintahan. Malang: Universitas Muhammadiyah Malang.

Hadjon, P. M. (1997), tentang Wewenang. YURIDIKA, 11-22.

Iskandar, A. (1998). Pedoman Perencanaan dan Pengoperasian Fasilitas Parkir. Jakarta: Direktorat Bina Sistem Lalu Lintas dan Angkutan Kota Direktorat Jenderal Perhubungan Darat.

Kusdi. (2009). Teori Organisasi dan Administrasi. Jakarta: Salemba Humanika.

Lotulung, P. E. (1994). Himpunan Makalah Asas-Asas Umum Pemerintahan yang baik,.

Citra Aditya Bakti: Bandung.

Mahadi. (2003). Falsafah Hukum Suatu Pengantar. Bandung: Alumni.

Nawawi, I. (2009). Public Policy: Analisis, Strategi Advokasi Teori, dan Praktek. Surabaya: PMN.

Notohamidjoyo, O. ( 1975). Demi Keadilan Dan Kemanusiaan: Beberapa Bab Dari Filsafat Huku. Jakarta: Gunung Mulia.

Nurmandi, A. (2006). Manajemen Perkotaan. Yogyakarta.: Sinergi Publishing. 
Pratama, E. A. (2020). Business Ethics And Legal Liability In The Management Of State-Owned Enterprises. Journal of Critical Reviews, 7(15), 1401-407. Retrieved from http://www.jcreview.com/?mno=22413

Putera, H. H. (2010 ). Cara Praktis Menyusun \& Merancang Peraturan Daerah; Suatu Kajian Teoritis \& Praktis Disertai Manual; Konsepsi Teoritis Menuju Artikulasi Empiris. Jakarta: Kencana Prenada Media Group,.

Rahardjo, A. (2011). Pengelolaan Pendapatan dan Anggaran Daerah. Yogyakarta: Garaha Ilmu.

Rohman, A. S. (2012). Mempercepat Penanggulangan Kemiskinan dengan Kemitraan.

Dalam "Flamma" (edisi 34)., Manifesto: Memperkuat Representasi Politik Warga. Manifesto, 4-6.

Rohman, A. T. (2016). Implementasi Kebijakan melalui Kualitas Pelayanan Penerimaan Pajak Daerah dan Implikasinya terhadap Kepuasan Masyarakat di Dinas Pendapatan Kabupaten Kuningan. Bandung: Universitas Pasunda. Retrieved from http://repository.unpas.ac.

Rye, T. (2011). Manajemen Parkir: Sebuah Kontribusi Menuju Kota yang Layak Huni.

Terjemahan Harya Setyaka. . Eschborn: Federal Ministry for Economic Cooperation and Development (BMZ).

Soekanto, S. (2006). Metode Penelitian Hukum. Jakarta: Rajawali Press.

Suwarno, M. (2012). Strategi Pemerintahan: Manajemen Organisasi Publik. Jakarta: Erlangga.

Syafrudin, A. (2000). Menuju Penyelenggaraan Pemerintahan Negara yang Bersih dan Bertanggungjawab. Jurnal Pro Justisia, 66-87.

Syamsu, A. (2012). Analisis Kebijakan Publik: Kebijakan Sosisal di Perkotaan sebagai Kajian Implementatif. Jurnal Ilmiah Pemerintahan, 1(3), 35-54.

Widodo, J. (2001). Good Governance Telaah Dari Dimensi Akuntabilitas, Kontrol Birokrasi Pada Era Desentralisasi dan Otonomi Daerah. Surabaya: Insan Cendekia. 
DIKTUM: JURNAL ILMU HUKUM ISSN: 2655-3449 (E) - 2338-5413 (P) | Volume 8 No. 2 | November 2020 GEDUNG Q FAKULTAS HUKUM UNIVERSITAS PANCASAKTI TEGAL

Jl. Halmahera Km. 01, Kota Tegal | Telepon: (0283) 358745 Website: www.diktum.upstegal.ac.id | email: diktum@upstegal.ac.id

William, D. (2003). Analisis Kebijakan Publik. Yogyakarta: Gadjah Mada University Press. 